\title{
DAMPAK AKTIVITAS PRODUKSI TAMBANG SEMEN TONASA TERHADAP PERUBAHAN TINGKAT KESEJAHTERAAN MASYARAKAT KABUPATEN PANGKAJENE DAN KEPULAUAN
}

\section{(Changging Impact of Mine Operating Activities Cemen Production Tonasa to Rate Pangkajene and Archipelago Region Public Welfare)}

\author{
Nurlaila $^{1)}$, Endriatmo Soetarto ${ }^{1)}$ \\ 1) Departemen Sains Komunikasi dan Pengembangan Masyarakat, Fakultas Ekologi Manusia, \\ Institut Pertanian Bogor, Darmaga Bogor 16680, Indonesia \\ Email: nurlaila.ipb@gmail.com; endriatmo@apps.ipb.ac.id
}

\begin{abstract}
Indonesia's population growth has increased. This increase was not followed by the addition of the amount of area available on earth. Around 237641326 Indonesian people now have to rely on the environment that will animate them. Became one of the industry's growth efforts for the country to be able to improve the welfare of its people. Results from this study showed that the difference Based Wilcoxon test, there were no significant differences in welfare conditions before and after the cement maker, $Z=-0.089 ; p>0.05$, which means that the presence of these companies do not improve the welfare of the community objective. Based on the results of Spearman Rank correlation there is a significant correlation between changes in the agrarian structure and the level of prosperity in the pre-construction period (20 years), $r(41)=0,030 ; p<0.05$, and the correlation between the two was significant $(p<0.05)$. The condition of public welfare changes caused by changes in the agrarian structure which occurred before the company operates so as to encourage changes in the landscape and community involvement.
\end{abstract}

Keywords: mine production, agrarian structure, landscape changing

\begin{abstract}
ABSTRAK
Pertumbuhan penduduk Indonesia mengalami peningkatan. Peningkatan ini tidak diikuti dengan penambahan jumlah wilayah yang tersedia di muka bumi. Sekitar 237.641.326 jiwa penduduk Indonesia kini harus menggantungkan hidupnya pada lingkungan yang akan menghidupkan mereka. Pertumbuhan industri menjadi salah satu usaha bagi negara untuk dapat meningkatkan kesejahteraan masyarakatnya. Hasil dari penelitian ini menunjukkan bahwa berdasarkan uji perbedaan Wilcoxon, tidak terdapat perbedaan yang signifikan pada kondisi kesejahteraan sebelum dan setelah adanya perusahaan semen, $Z=-0,089 ; p>0,05$ yang artinya dengan adanya perusahaan tersebut tidak meningkatkan kesejahteraan objektif masyarakat. Berdasarkan hasil korelasi Rank Spearman terdapat hubungan yang signifikan antara perubahan struktur agraria dan tingkat kesejahteraan pada waktu praconstruction (20 tahun terakhir), $r(41)=0,030 ; p<0,05$ serta korelasi antara keduanya signifikan $(p<0,05)$. Kondisi kesejahteraan masyarakat mengalami perubahan yang diakibatkan oleh perubahan struktur agraria yang terjadi sebelum perusahaan beroperasi sehingga mendorong perubahan bentang alam dan pelibatan masyarakat.
\end{abstract}

Kata kunci : produksi tambang, struktur agraria, perubahan bentang alam 


\section{PENDAHULUAN}

Tanah merupakan sumber agraria yang dalam bahasa Latin disebut sebagai ager. Pada Kamus Besar Bahasa Indonesia menjelaskan mengenai agraria sebagai tanah dan dihubungkan dengan usaha pertanian. Agraria mula-mula adalah tanah, di atas tanah terdapat tumbuhan sehingga disebutnya pertanian atau kehutanan, terdapat air sehingga disebutnya pesisir atau kelautan, terdapat materi mineral sehingga disebutnya pertambangan dan perairan (Nashih, et al. 2010). Nashih, et al. (2010) menjelaskan agraria sebagai ruang hidup bagi manusia, tetumbuhan, hewan, dan kehidupan ekologi itu sendiri, serta hubungan yang terjalin di antara kesemua makhluk itu.

Undang-Undang Dasar Negara Republik Indonesia telah mengatur secara umum mengenai prinsip penguasaan dan pengusahaan kekayaan alam Indonesia, baik yang di atas bumi (tanah), air dan terkandung di dalamnya sebagai kekayaan alam yang dikuasai oleh negara dan dipergunakan untuk sebesar-besar kemakmuran rakyat. UUPA sebagai produk yang telah dilahirkan pada pendiri bangsa yang tidak hanya suatu konstruksi legal atas aturan pertanahan baru, namun juga cerminan dari aspirasi politik, tuntutan sosial dan budaya yang menghendaki penjebolan total struktur kolonial dan feodal yang demikian liat membelit struktur penguasaan sumber daya agraria Indonesia (Soetarto dalam Nashih, et al. 2010).

Peningkatan perekonomian dan pembangunan telah dimulai sejak tahun 1966. Perkembangan aktifitas pertambangan di Indonesia mulai berkembang setelah Soekarno jatuh, dan digantikan oleh rezim orde baru yang dipimpin oleh Soeharto. Pada masa pemerintahannya terbit UU tentang Penanaman Modal Asing yakni UU No. 1 Tahun 1967. Undang-undang ini menjadi awal masuknya modal asing dalam pertambangan. Kelahiran UUPA 1960 mengundang lahirnya UU Penanaman Modal Asing 1967 dan UU Pokok Kehutanan 1967 yang semakin menjauhkan tanah dari tangan rakyat bahkan penguasaan oleh negara karena justru jatuh ke tangan pemilik modal (domestik/asing), serta mensektoralisasikan urusan agraria di bawah rezim-rezim penguasaan tersebut (Soetarto dalam Nashi, et al. 2010).

Pertambangan menjadi salah satu penghasil devisa terbesar negara terus mengeksploitasi yang menjadi hak masyarakat Indonesia, terutama masyarakat lokal yang berada di sekitar tambang sebagai penerima dampak terbesar. Pertumbuhan pertambangan akan diikuti dengan perubahan struktur agraria yang mendorong masyarakat untuk tetap mempertahankan tanahnya sebagai sumber kehidupan. Permasalahan tanah menjadi permasalahan lingkungan yang sangat mendasar berkaitan dengan populasi manusia pada tingkat kepadatan penduduk yang yang telah mencapai 237.641.326 ${ }^{1}$ jiwa, kebutuhan akan pangan, bahan bakar, pemukiman dan kebutuhan dasar lainnya yang pada gilirannya akan meningkatkan limbah domestik dan limbah industri, terutama di negara sedang berkembang (Kristanto 2002).

Berdasarkan data dari Kementrian Energi dan Sumber Daya Mineral (2014), terdapat sebanyak 3922 ijin eksplorasi, operasi dan produksi hasil tambang dan sekitar 1461 terdaftar sebagai lokasi tambang yang tidak clean and clear karena berbagai penyimpangan, seperti area tumpang tindih dengan konsesi pertambangan lain atau dengan konsesi pertanian. Pertumbuhan industri pertambangan juga semakin marak dengan permainan serta kolaborasi dari pihak-pihak yang terkait. Terbukti banyaknya perizinan tambang tidak dapat terkontrol, setidaknya setiap hari sekitar 6-7 Izin Usaha Pertambangan (IUP) dikeluarkan sejak 2008 (Hukum Online, Jumat 13 Januari 2013). Jika sekitar 1461 wilayah tambang yang tidak clean and clear namun sebanyak 5171 IUP dari 8263 telah mengantongi kategori clean and clear berdasarkan UU No.4 Tahun 2009 tentang pertambangan dan Batubara (Minerba).

Bersamaan dengan program pembangunan yang kian marak dicanangkan, pabrik Semen Tonasa II yang telah didirikan sejak 1968 juga menjadi salah satu perusahaan tambang yang menyumbangkan sumbangsihnya pada pertumbuhan yang diharapkan oleh negara. Di

\footnotetext{
${ }^{1}$ Badan Pusat Statistika (BPS 2014)
} 
balik dari dukungannya terhadap pertumbuhan ekonomi negara, PT Semen Tonasa sebagai salah satu pemangku kepentingan, melihat masyarakat sebagai bagian dari perseroan yang menjadi indikator sekaligus pihak yang mendapat multiplier effect dari perkembangan bisnis perseroan tersebut. Tanggung jawab perseroan kepada masyarakat dan lingkungan sekitar diwujudkan dengan kewajiban perseroan untuk mengalokasikan bagian keuntungan perusahaan guna mendukung peningkatan kualitas kehidupan masyarakat sekitar di bidang ekonomi dan sosial.

Kegiatan program kemitraan dan bina lingkungan (PKBL) serta organisasi keagamaan rutin dilaksanakan pada masayarakat lingkar tambang yang bertujuan untuk meningkatkan kesejahteraan dan taraf hidup masyarakat. Hal ini juga telah tertuang dalam UU No. 40 Tahun 2007 pasal 74 ayat 1 tentang Perseroan yang menjalankan kegiatan usaha dan berkaitan dengan sumber daya alam, tanggung jawab sosial dan lingkungan. Selain itu, perusahaan juga mengembangkan kegiatan di bidang kesehatan masyarakat dan lingkungan dengan program sehat Tonasa, pendidikan dengan Cerdas Tonasa, Ekonomi dengan Bina Mitra Tonasa serta lingkungan dengan Program Desa Mandiri Tonasa. Berdasarkan kegiatan yang dibentuk oleh perusahaan juga untuk menjalankan Green Industry yang telah diterima dalam sertifikat sistem manajemen lingkungan ISO 14001 dari SGS Yarsley International Sertifications Services and Limited.

Hasil penelitian berbagai aktivis lingkungan (kabarkami.com edisi 12 November 2014) menunjukkan aktivitas pertambangan kapur yang dilakukan secara besar-besaran (PT Semen Tonasa dan Bosowa) telah mencapai luas daerah operasi 2357,7 Ha yang setiap tahunnya areal eksploitasi yang dilaksanakan oleh 24 perusahaan penambangan telah mencapai 15-25 Ha untuk tiap perusahaan, termasuk PT. Semen Tonasa. Sejak puluhan tahun silam, kawasan karst yang berada pada kawasan hutan taman nasional saat ini telah dikuasai oleh segelintir elit dan telah mengalami eksploitasi secara besar-besaran oleh perusahaan tambang negara dan swasta di Sulawesi Selatan dalam bentuk pertambangan batu gamping untuk semen, marmer dan industri lainnya menjadi kepentingan utama sejumlah pemilik modal. Berbagai industri pertambangan yang terus berkembang maka dapat memicu perebutan atas penggunaan dan penguasan akan sumber daya alam terutama tanah, selain itu aktivitas pertambangan akibat eksplorasi yang semakin marak dilaksanakan menunjukkan bahwa operasi produksi tambang akan sering dilaksanakan begitu pun dengan aktivitas pertambangan kapur yang telah berlangsung selama 64 tahun oleh PT Semen Tonasa serta Semen Bosowa dengan luas daerah operasi produksi tambang telah mencapai 2534,7 Ha dan setiap tahun mengalami penambahan areal eksploitasi yang dilaksanakan oleh 24 perusahaan penambangan yang terdapat di Sulawesi Selatan saat ini (hasil penelitian dari beberapa aktivis untuk lingkungan) sehingga dari aktivitas pertambangan ini yang akan didalami adalah Sejauhmana dampak aktivitas operasi proses produksi tambang PT Semen Tonasa terhadap kesejahteraan masyarakat lingkar tambang?

Wilayah Indonesia dikenal memiliki potensi tambang terbesar di dunia. Pertambangan di Indonesia menjadi penyumbang devisa terbesar negara dengan hasil alam yang melimpah. Pertambangan menjadi salah satu bentuk pembangunan berkelanjutan. Pada UU No. 32 Tahun 2009 dijelaskan bahwa pembangunan berkelanjutan sebagai salah satu upaya yang terencana untuk memadukan aspek lingkungan hidup, sosial, dan ekonomi ke dalam strategi pembangunan untuk menjamin keutuhan lingkungan hidup serta keselamatan, kemampuan, kesejahteraan, dan mutu hidup generasi masa kini dan masa depan. PT Semen Tonasa dengan pengelolaan tambangnya berupaya untuk tetap melaksanakan Green Industry. Maka dari itu, berdasarkan pernyataan diatas dirumuskan pertanyaan, Sejauhmana kegiatan produksi tambang PT Semen Tonasa mendorong terjadinya perubahan struktur agraria pada masyarakat Dusun Boronguntia?

Kegiatan pertambangan yang dilaksanakan dalam tahapan operasi produksi adalah kegiatan usaha pertambangan yang meliputi konstruksi, penambangan, pengolahan, pemurnian, 
termasuk pengangkutan dan penjualan serta sarana pengendalian dampak lingkungan sesuai dengan studi kelayakan (UU Minerba No. 4 Tahun 2009). Melihat kegiatan yang terdapat dalam operasi produksi menunjukkan gambaran bahwa banyaknya kegiatan dalam tahapan operasi produksi akan menimbulkan perubahan yang akan berlangsung cepat. Dirumuskan pertanyaan bahwa Sejauhmana kegiatan produksi tambang PT Semen Tonasa melibatkan masyarakat lingkar tambang pada kegiatan industri?

Kegiatan pertambangan pada operasi produksi akan menunjukkan bentuk perubahan bentang alam yang terjadi selama berlangsungnya kegiatan pertambangan. Upaya pengelolaan usaha tambang galian terbuka dapat menunjukan hasil dari pembangunan berkelanjutan yakni peningkatan kesejahteraan masyarakat lingkar tambang sebagai penerima dampak dari operasi produksi tambang. Berdasarkan hal tersebut pertanyaan dirumuskan Sejauhmana dampak kehadiran perusahaan PT Semen Tonasa terhadap tingkat kesejahteraan masyarakat Dusun Boronguntia?

Tujuan penelitian ini adalah mengkaji permasalahan dampak tambang terhadap kesejahteraan masyarakat lingkar tambang, tujuan khususnya ialah menjawab pertanyaan permasalahan, yakni :

1. Mengidentifikasi kegiatan produksi tambang PT Semen Tonasa yang mendorong terjadinya perubahan struktur agraria terhadap masyarakat Dusun Boronguntia;

2. Mengidentifikasi kegiatan produksi tambang PT Semen Tonasa dalam melibatkan masyarakat lingkar tambang pada kegiatan pertambangan;

3. Mengidentifikasi dampak kehadiran perusahaan terhadap tingkat kesejahteraan masyarakat Dusun Boronguntia.

\section{PENDEKATAN LAPANG}

Pendekatan penelitian yang dilakukan adalah pendekatan kombinasi terhadap kuantitatif dengan pendekatan kualitatif. Studi ini akan dilakukan dengan menampilkan studi kasus pada wilayah penelitian dan memberikan gambaran pada kondisi wilayah penelitian. Penelitian kuantitatif diperoleh dengan menggunakan survei melalui instrumen kuesioner yang ditujukan kepada responden untuk mengetahui kondisi sosial ekonomi masyarakat penerima dampak pada kawasan lingkar tambang serta tingkat kesejahteraan masyarakat lingkar tambang dari segi subyektif dan obyektif. Sedangakan pendekatan kualitatif dilaksanakan dengan menggunakan teknik wawancara mendalam kepada informan serta melalui pengamatan berpartisipasi serta studi dokumen untuk menggali data, menganalisis, dan menelusuri fenomena perubahan struktur agraria yang mempengaruhi tingkat kesejahteraan di tanah Semen Tonasa, Dusun Boronguntia, Desa Biringere, Kecamatan Bungoro. Selain itu juga untuk mendapatkan informasi terkait struktur agraria dan profil desa.

Pengambilan data dilakukan melalui dua tahap. Tahap pertama adalah pengambilan data melalui kuesioner yang dibagikan kepada responden dan tahap kedua dengan indeep interview pada informan. Kemudian setelah diuji, maka akan dilakukan editing kuesioner sebagai penelitian sesungguhnya yang disesuaikan dengan karakteristik masyarakat dan daerah lokasi penelitian. Hal ini dilakukan agar data yang diperoleh dapat terjamin, baik realibitas maupun validitasnya.

Penelitian dilakukan di Dusun Boronguntia, Desa Biringere, Kecamatan Bungoro, Kabupaten Pangkajene dan Kepulauan. Data yang dikumpulkan adalah data primer dan data sekunder. Data primer diperoleh melalui pengamatan langsung di lapangan dan juga melalui wawancara terstruktur dengan para responden yang telah dipilih, sedangkan data sekunder diperoleh dari berbagai literatur dan sumber pustaka yang dapat digunakan untuk berbagai konsep dan teori yang berkaitan dengan masalah yang diteliti.

Penelitian ini mempunyai dua jenis data yang akan diolah dan dianalisis yaitu data kuantitatif dan kualitatif. Data Kualitatif menggunakan aplikasi NVIVO untuk memudahkan peneliti dalam penguatan pernyataan responden dan informan serta membantu pembuatan teori baru. Data kuantitatif menggunakan aplikasi 
Microsoft Excel 2010 dan IBM SPSS for Window 16.0.

\section{HASIL DAN PEMBAHASAN}

\section{Perubahan Struktur Agraria}

Masuknya industri pertambangan di sekitar pemukiman masyarakat telah mengubah struktur kehidupan masyarakat, terutama pada mata pencahariannya. Aksi penuntutan yang dilakukan oleh masyarakat sebagai bukti kondisi masyarakat hanya bergantung pada perusahaan. Kegiatan pertambangan adalah kegiatan yang dapat dilihat dari proses eksplorasi hingga menghasilkan output. Jika dilihat dari dampak keberadaan perusahaan, harusnya mampu memberikan perubahan yang positif terhadap masyarakat lingkar. Pengaruh positif kegiatan penambangan yaitu memberikan kontribusi terhadap peningkatan pendapatan asli daerah, membuka keterisolasian wilayah, menyumbangkan devisa negara, membuka lapangan kerja, pengadaan barang dan jasa untuk dikonsumsi dan yang berhubungan dengan kegiatan produksi, serta dapat menyediakan prasarana bagi pertumbuhan sektor ekonomi lainnya (Mangkusubroto 1995).

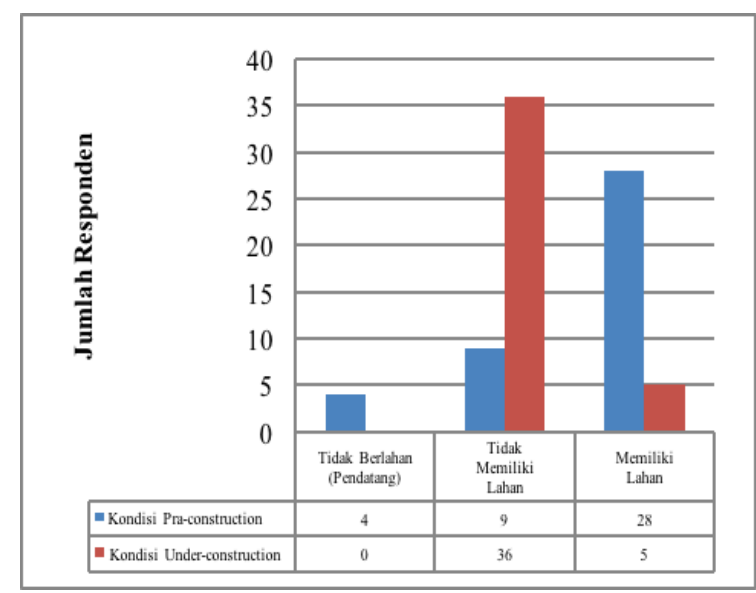

Gambar 1 Perubahan Struktur Agraria Di Dusun Boronguntia

Berdasarkan data pada Gambar 1, terlihat bahwa luasan lahan yang dapat digunakan oleh masyarakat adalah luasan yang rata-rata berada pada kondisi sedang yakni sebanyak 20 responden dan sebanyak 13 responden berada pada kondisi rendah serta sebanyak 8 responden berada pada kondisi tinggi. Mengacu pada data tersebut terlihat bahwa masyarakat hanya dapat memanfaatkan lahan berupa lahan adat dan hanya digunakan untuk membangun rumah. Rata-rata penggunaan lahan yang dapat digunakan masyarakat untuk membangun rumah adalah seluas $104.41 \mathrm{Ha}$ tanpa terdapat lahan tambahan untuk digunakan sebagai kegiatan pertanian lainnya.

Perubahan struktur agraria yang terjadi pada masyarakat lingkar tambang terutama Dusun Boronguntia telah mengalami perubahan yang sangat besar dan sangat signifikan. Hasil ini telah menggambarkan mengenai kondisi agraria masyarakat yang sudah tidak memiliki lahan pertanian, tidak dapat memanfaatkan bahkan tidak dapat menggunakannya lagi apalagi menyewa. Hanya sebagian kecil yang dapat menggunakannya itupun hanya sebagai buruh bukan sebagai penyewa dan penggarap lahan.

\section{Perubahan Bentang Alam}

Berdasarkan Gambar 2 maka dapat diperoleh gambaran bahwa kondisi bentang alam yang terjadi semenjak perusahaan semen beroperasi menunjukkan kondisi sedang. Responden yang berada pada kondisi buruk hanya ditunjukan oleh 1 orang responden $(2.4 \%)$, pada kondisi sedang yakni sebanyak 38 responden $(92.7 \%)$ sedangkan untuk kondisi baik hanya terdapat 2 orang $(4.9 \%)$.

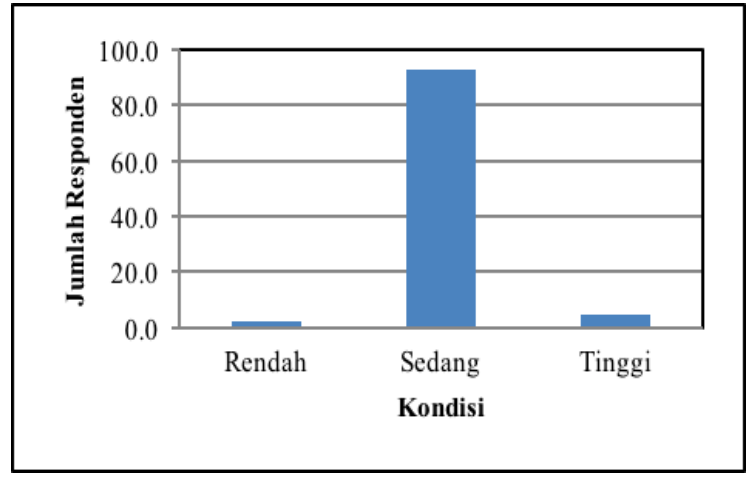

Gambar 2 Perubahan Bentang Alam di Dusun Boronguntia

Berdasarkan data tersebut, terlihat bahwa perusahaan memberikan perubahan pada 
kondisi bentang alam Dusun Boronguntia. Perubahan bentang alam yang terlihat oleh masyarakat adalah kondisi pemilikan lahan, kondisi infrastruktur (jalan), kondisi pemukiman terutama akibat ledakan yang menghasilkan getaran sehingga kondisi rumah warga menjadi retak, serta kondisi udara yang pada musim kemarau akan sangat terasa polusi yang dihasilkan oleh pabrik.

Kondisi perubahan lain dirasakan oleh masyarakat adalah pada perubahan kondisi lingkungan, dimulai dari kondisi tanah yang tidak sesubur dahalu, pekarangan yang tidak dapat ditanami untuk pemanfaatan lahan akibat kondisi lingkungan yang semakin dipadati oleh pemukiman, polusi dari aktivitas pabrik yang debunya tidak dapat dihindari lagi hingga menyebabkan kondisi kesehatan masyarakat yang sering sesak napas, flu, hingga mengalami ISPA dan sinusitis. Ledakan dari kegiatan pencarian karst sebagai bahan baku pembuatan semen menyebabkan masyarakat sudah tidak asing dan kaget jika terjadi ledakan-ledakan tersebut. Sehari bisa saja merasakan getaran tersebut sebanyak dua kali. Ledakan itu rupanya menyebabkan kondisi rumah warga retak hingga terjadi pergeseran tanah.

\section{Pelibatan Masyarakat Lokal}

Kondisi peluang usaha dengan adanya Tonasa berimbang antara kondisi yang rendah dan sedang, sebanyak 16 responden (39.0 \%) mengatakan berada kondisi yang rendah, kondisi sedang sebanyak 16 responden atau 39.0 persen, dan sebanyak 9 responden $(22.0$ $\%)$ mengatakan pada kondisi tinggi. Kondisi di atas menunjukkan bahwa peluang usaha atau kerja yang digambarkan oleh responden beragam (lihat Gambar 3).

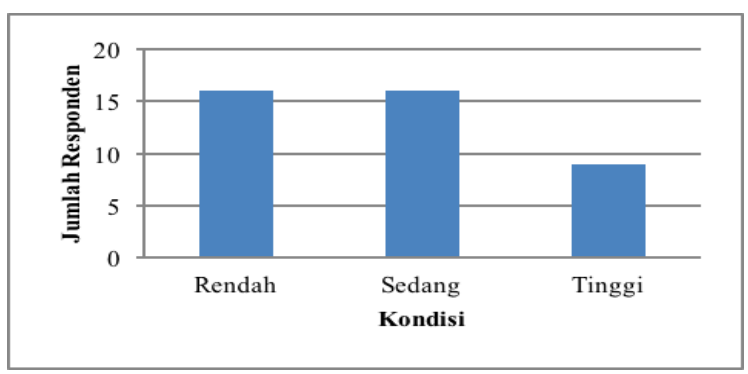

Gambar 3 Peluang Usaha atau Kerja Masa Under-Construction Menurut
Responden Desa Boronguntia Tahun 2015

Mengacu pada kondisi pendapatan dan pengeluaran yang mengalami peningkatan, maka dapat dipastikan bahwa keberadaan perusahaan akan membuka peluang bagi masyarakat lokal untuk ikut terlibat dalam kegiatan baik di industri maupun di pertambangannya. Penerimaan tenaga kerja yang dilakukan oleh perusahaan untuk mendukung kegiatan operasional meliputi, tenaga managerial, teknis tambang, teknis operasional dan tenaga kerja pendukung. Salah satu contoh kasus disajikan pada jumlah kebutuhan tenaga kerja yang telah direkrut oleh perusahaan Semen Tonasa yang beroperasi di daerah Desa Biringere, Dusun Boronguntia (Tabel 1).

Jumlah tenaga kerja yang dibutuhkan oleh perusahaan terutama dalam kegiatan pertambangan menunjukkan bahwa masyarakat lokal memiliki kesempatan untuk dapat terlibat. Namun, terlihat bahwa adanya permainan yang terjadi tidak hanya dalam pemerintahan, mencari peluang usaha atau kerja saja masih butuh persaingan tidak sehat, hingga memiliki jaringan sangat dibutuhkan untuk melancarkan segala urusan, terutama jika memiliki jaringan dengan orang dalam.

Tabel 1 Kebutuhan tenaga kerja PT Semen Tonasa untuk operasional tambang semen di Desa Biringere

\begin{tabular}{|l|l|c|l|}
\hline No & Jenis Pekerjaan & $\begin{array}{c}\text { Jumlah } \\
\text { Tenaga } \\
\text { Kerja } \\
\text { (Orang) }\end{array}$ & Pendidikan \\
\hline 1 & Tenaga Pengamat & 9 & SLTA, S1, S2 \\
\hline 2 & Mandor & 22 & SLTA, S1 \\
\hline 3 & Pelaksana/Pekerja & 113 & SD s/d S1 \\
\hline \multicolumn{2}{|l}{ Total } & $\mathbf{1 4 4}$ & \\
\hline
\end{tabular}

Sumber : PT. Semen Tonasa, 2014

Selain adanya penyerapan tenaga kerja di perusahaan, peningkatan penghasilan per bulan juga dibutuhkan dan diterima oleh masyarakat dengan adanya peluang usaha bagi masyarakat yang berada di sekitar tambang. Dominasi usaha yang dikembangkan oleh masyarakat adalah usaha dagang kelontong dan usaha ini akan berkembang jika menerima dana bantuan dari perusahaan pada program Bina Mitra Tonasa 
dan tidak semua pengajuan dapat diterima, karena perusahaan memiliki kriteria tersendiri untuk pemberian dana bantuan usaha ini.

Sinaga (1978) dituliskan bahwa pergeseran kesempatan kerja dari sektor pertanian ke sektor non-pertanian dapat diartikan sebagai (a) proporsi jumlah tenaga kerja yang bekerja di bidang pertanian semakin berkurang dan (b) tenaga kerja di bidang pertanian mencurahkan jam kerjanya di sektor pertanian berkurang dan mengalihkannya kepada pekerjaan lain di sektor non-pertanian. Juga hasil dari beberapa penelitian menyebutkan bahwa pergeseran tenaga kerja dari sektor pertanian ke sektor nonpertanian bukanlah karena gaya tarikan dari pendapatan yang lebih tinggi di sektor nonpertanian tetapi karena tenaga kerja terpaksa ke luar dari sektor pertanian dan menerima pekerjaan di luar sektor pertanian dengan upah yang lebih rendah.

Menyambung hasil penelitian di atas bahwa benar adanya pergesaran kesempatan kerja dari pertanian ke non-pertanian bukan karena dorongan pendapatan tetapi karena keterpaksaan yang mendorong masyarakat untuk bekerja di sektor non-pertanian dengan upah rendah. Keberadaan perusahaan di sekitar masyarakat dengan gaya industri yang ditawarkan memberikan pengaruh terhadap kawasan yang terlihat termarginalkan. Perbedaan kondisi wilayah pada satu kawasan menunjukkan mengenai kondisi sosial ekonomi masyarakat namun dengan kondisi mereka yang pendatang dan bekerja di perusahaan dengan masyarakat lokal yang dulu petani menjadi buruh di proyek perusahaan.

Masyarakat terpaksa terlibat dalam kegiatan indutri bukan hal yang mudah. Masyarakat juga butuh kenalan agar dapat ikut terlibat dalam pelaksanaannya walau hanya sebatas buruh proyek atau buruh tetap di perusahaan. Bertani ditinggalkan karena sudah tidak ada lahan yang dapat digarap, sehingga kesempatan untuk bekerja di perusahaan menjadi wadah pengganti bertani.

Berdasarkan pernyataan yang telah digambarkan bahwa kondisi perubahan struktur agraria digambarkan pada hasil uji beda pada Wilcoxon, yakni signifikansi sebesar $0.009<$
0.05 yang artinya terdapat perbedaan yang signifikan pada kondisi perubahan struktur agraria sebelum dan setelah adanya pabrik semen di sekitar pemukiman masyarakat dengan $\mathrm{Z}=-2.600 ; \mathrm{p}<0.05$. Data setelah memiliki rata-rata lebih kecil dibandingkan dengan data sebelum, yang Artinya dengan adanya perusahaan tersebut tidak meningkatkan perubahan struktur agraria di sekitar masyarakat. Perubahan pekerjaan membutuhkan waktu untuk disesuaikan, karena pekerjaan bukan hanya sekedar bekerja namun bekerja untuk masyarakat adalah mengumpulkan pundi-pundi uang demi keluarga.

\section{Perubahan Tingkat Pendapatan Masyarakat Under-Construction Dusun Boronguntia}

Perusahaan semen di tengah masyarakat akan menggambarkan kondisi kehidupan masyarakat. kondisi kehidupan dapat dilihat dari sejauhmana dan seberapa besar perubahan yang dirasakan oleh masyarakat, terutama pada pendapatan. Pendapatan dapat diukur dengan melihat kondisi pekerjaan hingga kondisi pemukiman. Tidak hanya itu, pendapatan juga dapat menunjukkan seberapa besar kemampuan masyarakat untuk memenuhi kebutuhan seharihari. Jumlah anggota keluarga juga menjadi alat ukur bahwa seberapa banyak anggota keluarga yang telah memiliki pekerjaan dan tinggal dalam satu rumah dengan kondisi dapur yang dihitung berdasarkan penyajian makanannya.

Berdasarkan Gambar 4, bahwa kondisi pendapatan masyarakat pada masa praconstruction berada pada kondisi sedang yang dibuktikan dengan sebanyak 8 responden (19.5 $\%$ ) berada pada kondisi pendapatan yang rendah, 26 responden atau 63.4 persen pada kondisi pendatan sedang atau disebut juga menengah, dan sebanyak 7 responden (17.1\%) berada pada kondisi pendapatan yang tinggi. Sedangkan bila dibandingkan pada kondisi under-construction maka dapat dilihat bahwa sebanyak 12 responden (29.3\%) berada pada kondisi pendapatan yang rendah dan sebanyak 29 responden atau 70.7 persen berada pada kondisi pendapatan yang tinggi. 


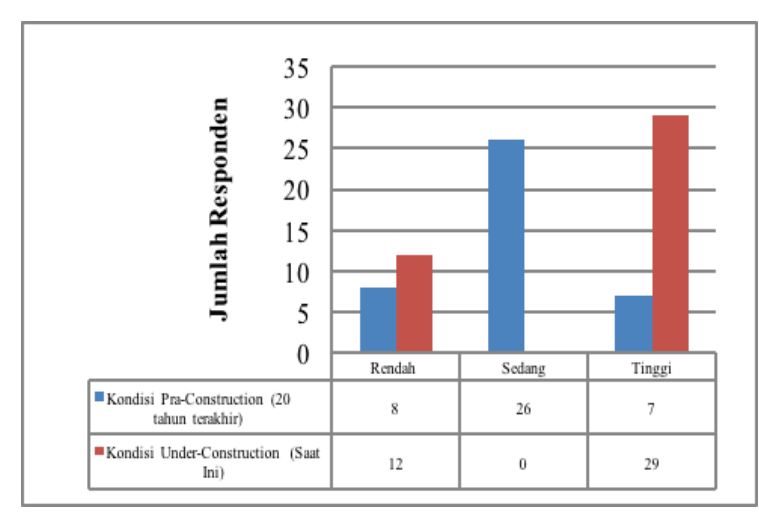

Gambar 4 Tingkat Pendapatan Masyarakat Under-Construction Dusun Boronguntia Tahun 2015

Merujuk dari hasil temuan tersebut, maka dapat diketahui bahwa kondisi perekonomian masyarakat terutama jika dilihat dari pendapatan masyarakat sebelum dan setelah pabrik semen beroperasi di sekitar kawasan pemukiman, mengalami perubahan pendapatan. Perubahan ini didukung oleh jenis pekerjaan dari masyarakat, selain itu juga dipengaruhi oleh perubahan dari kondisi desa yang telah mengalami transformasi serta akses yang memudahkan masyarakat untuk memperoleh jenis pekerjaan yang lain. Rata-rata pendapatan masyarakat sebesar Rp1 859 756,- setelah pabrik semen beroperasi sedangkan pada masa pra-construction berada pada rata-rata Rp837 $000,-$, tetapi peningkatan ini juga dapat dipengaruhi oleh faktor inflasi, sehingga kemungkinan peningkatan pendapatan juga dapat berasal dari inflasi juga pendapatan yang diperoleh dari hasil kerjanya di bawah naungan perusahaan tambang semen.

Dalam dimensi perubahan sosial, maka kondisi masyarakat telah digambarkan dengan kondisi mobilitas horisontal. Mobilitas ini menggambarkan bahwa kondisi masyarakat yang awalnya petani berubah menjadi buruh tidak merubah kedudukan masyarakat dalam tataran sosial, melainkan perubahan ini hanya sebatas perubahan jenis pekerjaan namun pendapatannya tidak mampu mengubah mobilitas masyarakat menjadi vertikal.

Sinaga (1978) dalam tulisannya juga memaparkan bahwa berdasarkan hasil-hasil penelitian bahwa baik bagi keluarga buruh tani tidak bertanah dan keluarga petani dengan usaha tani sempit maupun keluarga petani yang milik/garapan tanahnya luas, sumber pendapatan mereka dari luar usahatani merupakan proporsi yang cukup penting dari total pendapatan keluarga. Keluarga buruh tani tak bertanah dan petani dengan usahatani sempit pendapatan mereka dari sektor pertanian tidak mencukupi kebutuhan hidupnya oleh karena itu mereka harus mencari sumber pendapatan di luar sektor pertanian yang tidak atau hampir tidak membutuhkan kapital (misalnya berdagang kecil, kerajinan tangan, industri kecil dan jasa) walaupun dengan pendapatan per hari kerja yang rendah.

Kondisi pendapatan ini dijelaskan oleh Sinaga (1978) dengan menciptakan dua hal yang saling berhubungan erat yaitu : (1) marginalisasi dari sebagian terbesar angkatan kerja di pedesaan yang dicirikan oleh kekurangan faktor-faktor produksi non-labor dan menciptakan barisan tenaga pengangguran dan underemployed yang mengakibatkan tekanan kepada tingkat upah dan pendapatan tenaga kerja baik di sektor pertanian maupun di luar sektor pertanian, (2) terjadi akumulasi kapital baik di sektor pertanian dan nonpertanian pada segolongan elit (pemilik tanah luas dan pengusaha) di desa yang sangat akses terhadap kapital (baik dari usaha sendiri maupun dari lembaga-lembaga kredit dormil dan tenaga kerja yang murah).

\section{Tingkat Penguasaan Lahan dan Pendapatan Masyarakat}

Kaitan antara struktur agraria dan kesejahteraan petani sangat erat karena bagi para petani sumberdaya agraria merupakan sumber nafkah utama (Sitorus, dkk. 2008). Melalui pengusahaan sumberdaya lahan diharapkan para petani akan memiliki penghasilan yang cukup dan berkelanjutan, yakni Menurut Haan (200) dalam Sitorus, dkk. (2008) suatu mata pencaharian dapat dikategorikan sebagai mata pencaharian berkelanjutan bila terdapat kecukupan untuk memenuhi kebutuhan dasar (self-defined basicneed) serta menjamin orang untuk dapat menghadapi goncangan (shock) dan tekanan (Stress).

Kondisi penguasaan lahan yang sudah dimiliki oleh petani pada Dusun Boronguntia telah 
menggambarkan bahwa masyarakat tani saat ini sudah menjadi buruh, perubahan sosial telah menjadikan masyarakat mengalami mobilitas horisontal, yakni kondisi kesejahteraan yang hampir sama bahkan bisa dikatakan tidak sebaik sebelum perusahaan beroperasi. Kondisi tersebut dapat dilihat pada Gambar 4.

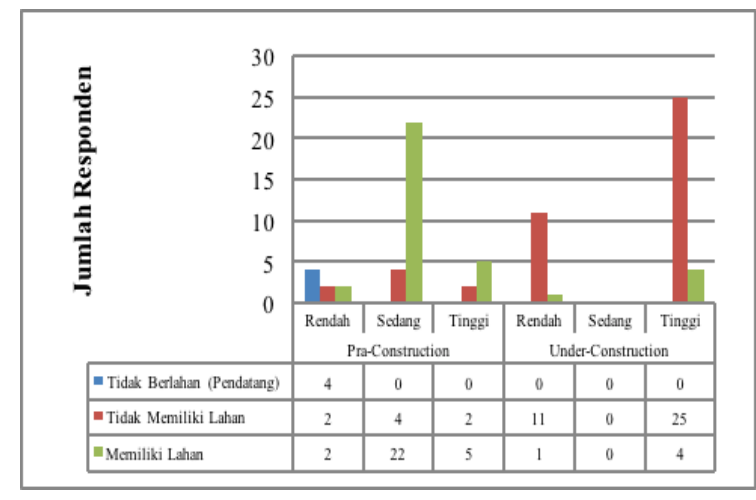

Gambar 5 Tingkat Penguasaan Lahan dan Pendapatan Masyarakat Boronguntia

Pada Gambar 4 telah menunjukkan bahwa kondisi pendapatan masyarakat pada kondisi pra-construction dengan status kepemilikan lahan dan pendapatan sedang sebanyak 22 responden dan yang tidak memiliki lahan dengan dengan pendapatan sedang sebanyak 4 responden, sedangkan untuk responden yang tidak memiliki lahan namun memiliki pendapatan tinggi hanya sebanyak 2 reponden, serta responden yang memiliki lahan dengan tingkat pendapatan tinggi sebanyak 5 responden.

Bila dibandingkan dengan kondisi underconstruction maka kondisi yang mengejutkan berada pada kondisi responden dengan status lahannya tidak memiliki namun pendapatan mereka tinggi (25 responden). Sehingga hasil ini menunjukkan sebuah kondisi baru pada masyarakat, meskipun mereka dulunya memiliki kekuasaan untuk mengatur sumberdaya yang dimilikinya namun saat ini, mereka hanya sebatas masyarakat upahan dengan tingkat mobilitas yang sama meskipun pendapatan mereka tinggi.

Pendapatan tinggi berasal bukan dari hasil tani, melainkan dari usaha atau kerja yang diperoleh oleh responden dalam melangsungkan kehidupan akibat perubahan yang dialami oleh masyarakat. Hal ini kemudian dikuatkan oleh Sajogyo (1985) bahwa sumberdaya lahan merupakan tempat tani berinvestasi dan mengakumulasikan kekayaan yang dapat ditransfer dari satu generasi ke generasi berikutnya. Oleh karena itu bentuk struktur penguasaan sumberdaya agraria (struktur agraria) termasuk lahan yang turut menentukan akses beragam lapisan dalam penguasaan sumberdaya agraria juga akan menentukan keada peta kesejahteraan keluarga/komunitas petani.

\section{Tingkat Kesejahteraan Masyarakat}

Kesejahteraan merupakan alat untuk untuk mengetahui kondisi masyarakat. Suharto (2005) menyebutkan dalam tiga konsep, yaitu :

1. Kondisi kehidupan atau keadaan sejahtera, yakni terpenuhinya kebutuhan-kebutuhan jasmaniah, rohaniah dan sosial (makanan, pakaian, perumahan, pendidikan dan perawatan kesehatan);

2. Institusi, arena atau bidang kegiatan yang melibatkan lembaga kesejahteraan sosial dan berbagai profesi kemanusiaan yang menyelenggarakan usaha kesejahteraan sosial dan pelayanan sosial;

3. Aktivitas, yakni suatu kegiatan-kegiatan atau usaha yang terorganisir untuk mencapai kondisi sejahtera.

Berdasarkan konsep diatas maka akan dilihat mengenai kondisi kesejahteraan masyarakat sebelum dan selama perusahaan masih beroperasi. Tingkat kesejahteraan akan menunjukkan tingkat ekonomi masyarakat. Untuk mengetahui tingkat kesejahteraan masyarakat dapat dilihat pada Gambar 6.

Berdasarkan hasil di lapang yang ditunjukkan pada gambar 5, dari berbagai reaksi yang responden sampaikan. Untuk melihat kesejahteraan masyarakat dilihat dari sudut pandang secara obyektif dan secara subyektif. Hal ini dimaksudkan bahwa jika secara sudut pandang obyektif berarti didasarkan pada keadaan yang dijalani, sedangkan secara subyektif dimaksudkan dengan yang dirasakannya. 


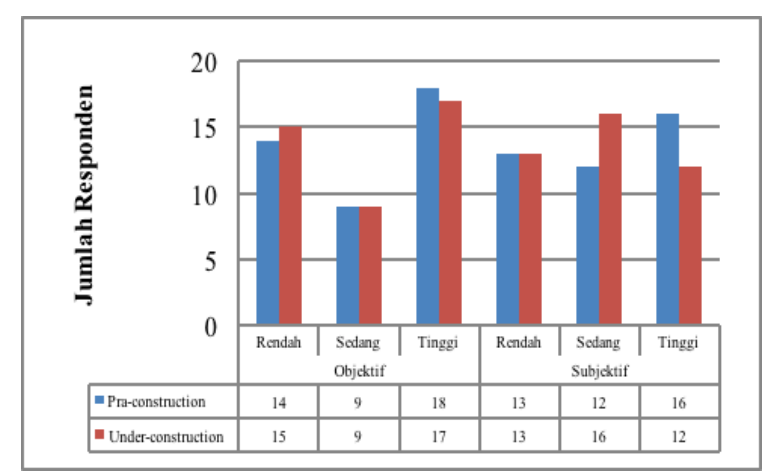

Gambar 6 Tingkat Kesejahteraan Masyarakat Dusun Boronguntia

Berdasarkan hasil di lapang yang ditunjukkan pada gambar 6, dari berbagai reaksi yang responden sampaikan. Untuk melihat kesejahteraan masyarakat dilihat dari sudut pandang secara obyektif dan secara subyektif. Hal ini dimaksudkan bahwa jika secara sudut pandang obyektif berarti didasarkan pada keadaan yang dijalani, sedangkan secara subyektif dimaksudkan dengan yang dirasakannya.

Pada kondisi pra-construction terlihat bahwa kesejahteraan masyarakat berada pada kondisi kelas tinggi yakni sebanyak 18 responden, dan secara subyektif hanya berada pada kondisi sedang yakni sebanyak 16 responden, selebihnya berada pada kondisi rendah. Sedangkan untuk kondisi under-construction kondisi kesejahteraan secara obyektif berada pada keadaan yang tinggi sama halnya pada kondisi subyektif juga berada pada kondisi tinggi.

Uji beda yang telah dilakukan nyatanya menunjukkan bahwa tidak banyak kepala keluarga yang mampu meningkatkan kesejahteraannya baik sebelum dan setelah perusahaan beroperasi, sehingga baik sebelum dan setelah perusahaan beroperasi tidak memberikan perubahan terhadap tingkat kesejahteraan masyarakat. Untuk mengetahui kondisinya akan dilihat satu per satu variabel yang berkaitan.

Gambar 7 menunjukkan bahwa variabel akses pendidikan berada pada tingkat kesejahteraan obyektif mengalami penurunan, yakni pada kondisi sedang dari 28 responden menjadi 20 responden, sedangkan pada kondisi rendah dan tinggi mengalami kenaikan dan paling terlihat adalah akses pendidikan yang semakin rendah dari 5 responden menjadi 11 responden yang menyatakan akses pendidikan saat ini rendah, tetapi berbeda pada sudut pandang subyektif, mereka menganggap akses pendidikan saat ini sudah lebih baik meskipun berada pada kondisi sedang yakni dari 14 responden menjadi 25 responden.

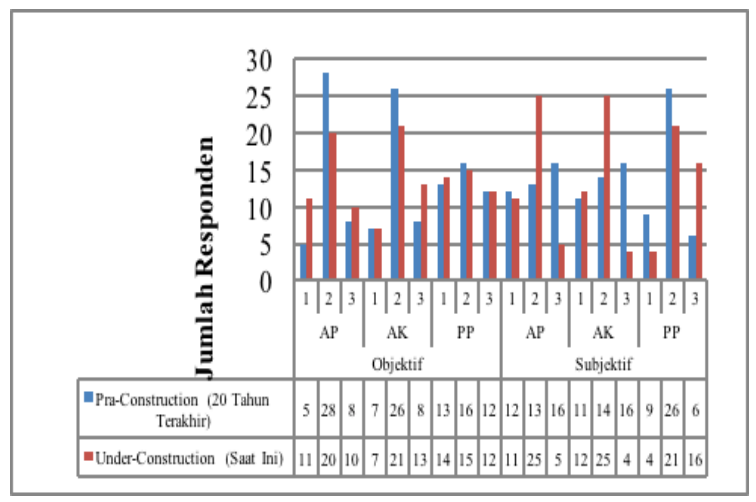

Gambar 7 Variabel Tingkat Kesejahteraan Responden Dusun Boronguntia Tahun 2015

Hal ini menggambarkan bahwa kondisi secara obyektif dialami diakibatkan karena kondisi sekolah yang dapat dikejar oleh masyarakat. jika dibandingkan dulu dengan sekarang perbedaan tersebut sangat mendasar terutama pada ketersediaan buku.

Selain varibel akses terhadap pendidikan, juga terdapat variabel akses terhadap kesehatan. Kesehatan salah satu alat ukur mengenai kesejahteraan masyarakat, sebab kesehatan sebagai modal untuk melaksanakan segala aktivitas yang menunjang kesejahteraan masyarakat. kesehatan sebagai modal untuk peningkatan kesejahteraan sehingga kesehatan menjadi alat ukur mengenai kondisi kesejahteraan dari masyarakat.

Berdasarkan kondisi yang digambarkan oleh responden, bahwa jika membandingkan kondisi akses kesehatan dulu dan sekarang memang telah jauh berbeda, bahkan akses kesehatan saat ini sudah dapat menggunakan BPJS yang sangat membantu masyarakat desa dengan keuangan yang sanat minim. Selain itu, akses kesehatan yang sangat memiliki pengaruh dan 
perubahan adalah pada pemenuhan obat dan ketersediaan dokter.

Selain variabel akses kesehatan dan akses pendidikan, hal terpenting untuk melihat kondisi kesejahteraan masyarakat adalah pada pemenuhan kebutuhan pokok. Pemenuhan kebutuhan pokok akan menunjukkan kondisi masyarakat untuk menjaga kestabilan hidupnya. Terpenuhinya kebutuhan dapat terlihat dari seberapa besar kemampuan kepala keluarga dalam memenuhi kebutuhan dapur. Jika pemenuhan kebutuhan pokok tidak terpenuhi maka akan menimbulkan kondisi yang menjadikan masyarakat berada pada posisi tingkat kesejahteraan dengan kesehatan yang rendah.

Pemenuhan kebutuhan pangan pokok disesuaikan dengan kondisi dari Badan Pusat Statistika. Pemenuhan kebutuhan pokok ini dilihat dari kebutuhan pangan, konsumsi rokok, bensin, hingga hiburan. Pemenuhan kebutuhan pangan sebagai langkah pengurangan kondisi malnutrisi dan kelaparan yang terjadi pada masyarakat di negara berkembang. Sama halnya dengan Dusun Boronguntia, sebagai salah satu dusun yang termarginal dari wilayah industri menggambarkan kondisi ini bisa sebagai gambaran kecil pada masyarakat yang berada di perkotaan besar.

Rusli (1992) dalam tulisannya yang bertajuk Penduduk dan Masalah Pangan di Indonesia menjabarkan bahwa setiap bangsa dewasa ini tidak hanya berkehendak mencegah terjadinya kelaparan massal dan bahaya kelaparan yang dahsyat melainkan juga berjuang untuk penyediaan pangan yang memadai bagi rakyat seluruhnya. Selain itu, dibutuhkan produksi pangan lokal di setiap daerah tergantung pada banyak faktor (Rusli 1992).

Berdasarkan pemaparan tersebut kemudian mengarahkan mengenai masalah pangan masalah kesejahteraan, maslah penangan mengenai kondisi. Dibutuhkan pula pangan lokal dengan faktor yang terpenting adalah luasan lahan yang dapat ditanami. Namun nyatanya, lahan yang kini telah menjadi milik perusahaan dan masih dipertanyakan status kepemilikannya sudah tidak mampu dimanfaatkan oleh masyarakat dalam pemenuhan kebutuhan pangan, hingga perubahan yang ditunjukkan mengalami perubahan yang sangat drastis. Hal tersebut diakibatkan oleh pola pemenuhan yang tadinya panen menjadi harus membeli dengan uang.

Berdasarkan data yang diperoleh dilapang, menunjukkan bahwa kondisi kesejahteraan responden sebelum dan saat pabrik beroperasi mengalami perubahan. Perubahan tersebut sebacara obyektif pemenuhan kebutuhan pokok masyarakat berada pada kondisi yang sedang ke rendah, yakni sebanyak 16 responden pada kondisi sedang dan 13 responden pada kondisi rendah pada masa pra-construction. Sedangkan pada masa under-construction mengalami penurunan, hingga kondisi kesejahteraan masyarakat dalam pemenuhan kebutuhan pokok tergolong rendah. Namun jika dilihat secara subyektif berdasarkan pernyataan responden kondisi kebutuhan pokok masyarakat saat ini lebih terpenuhi bila dibandingkan dengan kondisi sebelum perusahaan beroperasi.

Kondisi ini diakibatkan oleh keberadaan perusahaan yang mengubah kondisi penghidupan masyarakat sehingga pemenuhan tersebut dianggap lebih konsumtif dibandingkan sebelumnya, sebab masyarakat sebelum pabrik beroperasi menggantungkan kebutuhan pokoknya berdasarkan hasil lahan, sedangkan sekarang kebutuhan pokok dapat terpenuhi jika kepala keluarga mampu membeli kebutuhan pangan tersebut.

Jika melihat kondisi pemenuhan kebutuhan pokok dalam nominal rupiah, maka dapat dirata-ratakan bahwa selama satu bulan setiap kepala keluarga mampu menghabiskan uangnya sebanyak Rp752 256.00 sebelum pabrik beroperasi dan setelah pabrik beroperasi dapat menghabiskan dana sebanyak Rp2 041604.00 . Perbedaan dana yang sangat jauh bahkan perubahan tersebut tergolong sangat tinggi. Hasil rata-rata pengualaran dana terbesar setelah melakukan pengolahan data ditunjukkan pada pemenuhan kebutuhan pangan pada protein yakni ikan. Rata-rata setiap bulannya per kepala rumah tangga menghabiskan dana sekitar Rp648 780.00 untuk membeli ikan, yang bila dibandingkan dengan kondisi sebelum pabrik beroperasi hanya rata-rata $\mathrm{Rp} 316$ 585.00 . 


\section{Dampak Perubahan Struktur Agraria terhadap Kesejahteraan Masyarakat Dusun Boronguntia}

Dampak perubahan struktur agraria terhadap kesejahteraan masyarakat di Dusun Boronguntia dilihat dengan pendekatan kesejahteraan objektif dan kesejahteraan subyektif baik pada masa pra construction maupun under construction.

Tabel 2 menunjukkan hasil tabulasi silang responden berada pada tingkat perubahan struktur agraria yang baik. Berdasarkan hasil korelasi Rank Spearman terdapat hubungan yang signifikan antara perubahan struktur agraria dan tingkat kesejahteraan pada waktu pra-construction (20 tahun terakhir), r(41) = $0.030 ; p<0.05$ serta korelasi antara keduanya signifikan $(p<0.05)$. Artinya, semakin tinggi atau rendah perubahan struktur agraria yang terjadi pada masa pra-construction maka akan mempengaruhi tingkat kesejahteraan masyarakat pada 20 tahun terakhir.

Tabel 3 menunjukkan bahwa responden pada tingkat struktur agraria yang baik. Berdasarkan hasil korelasi Rank Spearman tidak terdapat hubungan yang signifikan antara perubahan struktur agraria dan tingkat kesejahteraan pada waktu under-construction (saat ini), $r(41)=$ $0.014 ; p<0.05$ serta korelasi antara keduanya sangat signifikan $(p>0,05)$. Artinya, semakin tinggi atau rendahnya perubahan struktur agraria yang terjadi pada masa pra-construction maka akan mempengaruhi tingkat kesejahteraan masyarakat pada masa 20 tahun terakhir.

Tabel 2 Jumlah dan persentase responden masyarakat lingkar tambang Dusun Boronguntia menurut kondisi perubahan struktur agraria pra-construction dengan tingkat kesejahteraan obyektif

Kondisi

\begin{tabular}{|c|c|c|c|c|c|c|c|c|}
\hline \multirow{3}{*}{ Perubahan Struktur Agraria } & \multicolumn{8}{|c|}{ Pra-Construction/20 Tahun Terakhir } \\
\hline & \multicolumn{2}{|c|}{ Rendah } & \multicolumn{2}{|c|}{ Sedang } & \multicolumn{2}{|c|}{ Tinggi } & \multicolumn{2}{|c|}{ Total } \\
\hline & $\mathrm{n}$ & $\%$ & $\mathrm{n}$ & $\%$ & $\mathrm{n}$ & $\%$ & n & $\%$ \\
\hline Buruk & 5 & 38.46 & 1 & 7.70 & 7 & 53.84 & 13 & 100 \\
\hline Sedang & 0 & 0.00 & 0 & 0.00 & 0 & 0.00 & $\mathbf{0}$ & $\mathbf{0}$ \\
\hline Baik & 9 & 32.14 & 8 & 28.57 & 11 & 39.28 & 28 & 100 \\
\hline
\end{tabular}

Tabel 3 Jumlah dan persentase responden masyarakat lingkar tambang Dusun Boronguntia menurut kondisi perubahan struktur agraria pra-construction dengan tingkat kesejahteraan subyektif

\begin{tabular}{|c|c|c|c|c|c|c|c|c|}
\hline \multirow{4}{*}{ Perubahan Struktur Agraria } & \multicolumn{8}{|c|}{ Kondisi } \\
\hline & \multicolumn{8}{|c|}{ Pra-Construction/ 20 Tahun Terakhir } \\
\hline & \multicolumn{2}{|c|}{ Rendah } & \multicolumn{2}{|c|}{ Sedang } & \multicolumn{2}{|c|}{ Tinggi } & \multicolumn{2}{|c|}{ Total } \\
\hline & $\mathrm{n}$ & $\%$ & $\mathrm{n}$ & $\%$ & $\mathrm{n}$ & $\%$ & $\mathbf{n}$ & $\%$ \\
\hline Buruk & 4 & 30.77 & 2 & 15.38 & 7 & 53.84 & 13 & 100 \\
\hline Sedang & 0 & 0.00 & 0 & 0.00 & 0 & 0.00 & $\mathbf{0}$ & 0.00 \\
\hline Baik & 9 & 32.14 & 10 & 35.71 & 9 & 32.14 & 28 & 100 \\
\hline
\end{tabular}

Tabel 4 menunjukkan bahwa responden pada tingkat struktur agraria yang baik. Berdasarkan hasil korelasi Rank Spearman tidak terdapat hubungan yang signifikan antara perubahan struktur agraria dan tingkat kesejahteraan pada waktu under-construction (saat ini), r(41) = $0.059 ; p>0.05$ serta korelasi antara keduanya tidak signifikan sama sekali $(p>0.05)$. Artinya, semakin tinggi atau rendahnya perubahan struktur agraria yang terjadi pada masa under- construction maka tidak akan mempengaruhi tingkat kesejahteraan masyarakat pada saat ini. 
Tabel 4 Jumlah dan persentase responden masyarakat lingkar tambang Dusun Boronguntia menurut kondisi perubahan struktur agraria under-construction dengan tingkat kesejahteraan obyektif

$$
\text { Kondisi }
$$

\begin{tabular}{lcccccccc} 
& \multicolumn{7}{c}{ Pra-Construction/ 20 Tahun Terakhir } \\
\cline { 2 - 11 } Perubahan Struktur Agraria & \multicolumn{2}{c}{ Rendah } & \multicolumn{2}{c}{ Sedang } & \multicolumn{2}{c}{ Tinggi } & \multicolumn{2}{c}{ Total } \\
\cline { 2 - 10 } & $\mathrm{n}$ & $\%$ & $\mathrm{n}$ & $\%$ & $\mathrm{n}$ & $\%$ & $\mathbf{n}$ & $\mathbf{\%}$ \\
\hline Buruk & 0 & 0 & 0 & 0 & 0 & 0 & $\mathbf{0}$ & $\mathbf{0}$ \\
\hline Sedang & 0 & 0 & 0 & 0 & 0 & 0 & $\mathbf{0}$ & $\mathbf{0}$ \\
\hline Baik & 15 & 100 & 9 & 100 & 17 & 100 & $\mathbf{4 1}$ & $\mathbf{1 0 0}$ \\
\hline
\end{tabular}

Tabel 5 Jumlah dan persentase responden masyarakat lingkar tambang Dusun Boronguntia menurut kondisi perubahan struktur agraria under-construction dengan tingkat kesejahteraan subyektif

\begin{tabular}{|c|c|c|c|c|c|c|c|c|}
\hline \multirow{4}{*}{ Perubahan Struktur Agraria } & \multicolumn{8}{|c|}{ Kondisi } \\
\hline & \multicolumn{8}{|c|}{ Pra-Construction/ 20 Tahun Terakhir } \\
\hline & \multicolumn{2}{|c|}{ Rendah } & \multicolumn{2}{|c|}{ Sedang } & \multicolumn{2}{|c|}{ Tinggi } & \multicolumn{2}{|c|}{ Total } \\
\hline & $\mathrm{n}$ & $\%$ & $\mathrm{n}$ & $\%$ & $\mathrm{n}$ & $\%$ & $\mathrm{n}$ & $\%$ \\
\hline Buruk & 0 & 0 & 0 & 0 & 0 & 0 & 0 & 0 \\
\hline Sedang & 0 & 0 & 0 & 0 & 0 & 0 & 0 & $\mathbf{0}$ \\
\hline Baik & 10 & 100 & 19 & 100 & 12 & 100 & 41 & 100 \\
\hline
\end{tabular}

Tabel 5 menunjukkan bahwa responden pada tingkat struktur agraria yang baik. Berdasarkan hasil korelasi Rank Spearman tidak terdapat hubungan yang signifikan antara perubahan struktur agraria dan tingkat kesejahteraan pada waktu under-construction (saat ini), $r(41)=$ $0.121 ; p>0.05$ serta korelasi antara keduanya tidak signifikan sama sekali $(p>0.05)$. Artinya, semakin tinggi atau rendahnya perubahan struktur agraria yang terjadi pada masa underconstruction maka tidak akan mempengaruhi tingkat kesejahteraan masyarakat pada saat ini.

\section{SIMPULAN DAN SARAN}

\section{Simpulan}

Kegiatan operasi produksi tambang semen telah mengubah kondisi sosial dan ekonomi masyarakat. Hasil penelitian menunjukkan bahwa kegiatan operasi produksi tambang semen yang tinggi menyebabkan perubahan struktur agraria yang secara tidak langsung dirasakan oleh masyarakat. Perubahan struktur agraria yang dialami oleh masyarakat yakni hilangnya status terhadap kepemilikan lahan sehingga masyarakat sudah tidak memiliki, tidak dapat menggunakan, dan tidak dapat memanfaatkan lahannya. Kegiatan produksi tambang semen yang tinggi sehingga mendorong tingginya perubahan struktur agraria pada masyarakat.

Selain itu, keberadaan perusahaan juga mendorong terjadinya peningkatan kesempatan kerja/usaha terhadap masyarakat Dusun Boronguntia terutama pada peluang kerja kegiatan pertambangan serta peluang untuk membuka usaha. Perubahan mata pencaharian sebagai bentuk penyesuaian yang dilakukan oleh masyarakat untuk dapat bertahan hidup. Tingginya aktivitas produksi tambang semen yang menyebabkan tingginya perubahan struktur agraria menjadikan masyarakat mengalami perubahan gaya hidup akibat perubahan jenis pekerjaan. Hasil penelitian dengan uji beda Wilcoxon telah menunjukkan bahwa terjadi perbedaan yang signifikan yakni pada masa pra-construction dan underconstruction. Kondisi ini ditunjukkan dengan kesempatan kerja yang diperoleh pada masyarakat sebatas perubahan mobilitas secara horisontal yakni dari petani menjadi buruh di pabrik semen.

Kehadiran perusahaan dijadikan sebagai alat ukur perubahan yang dialami oleh masyarakat. Kondisi masyarakat di sekitar kawasan pabrik 
dan perusahaan menjadikan masyarakat desa sebagai masyarakat yang termarginalkan. Hasil penelitian menunjukkan bahwa kondisi kesejahteraan masyarakat yang dihubungkan dengan keberadaan perusahaan dan aktivitas produksi yang tinggi menyebabkan kondisi kesejahteraan masyarakat mengalami peningkatan. Peningkatan yang terlihat pada kondisi under-construction dan peningkatan kesejahteraan yang sangat berhubungan adalah pada masa pra-construction saat perusahaan akan melaksanakan kegiatan pertambangan sehingga masyarakat mengalami perubahan struktur agrarianya.

\section{Saran}

Beberapa saran yang diajukan penulis berdasarkan hasil penelitian ini, yaitu :

1. Hak-hak masyarakat lingkar tambang Dusun Boronguntia perlu diperhatikan dan segera dipenuhi oleh perusahaan dan pemerintah daerah terkait kesejahteraan agar masyarakat dapat menjadi lebih baik.

2. Pemerintah daerah, Badan Pertanahan, dan perusahaan harus memiliki komunikasi dan korelasi kuat agar informasi mengenai lahan dapat dilaporkan dan transparansi terhadap berbagai lembaga yang berkaitan, sehingga pelaporan aktivitas dan keuangannya dapat diketahui dan dapat membantu peningkatan kesejahteraan daerah bahkan masyarakat yang berada di sekitarnya.

3. Kepada pihak perusahaan kemudian melihat kembali bentuk pendampingan yang dilaksanakan agar tidak sekedar menjalankan CSR dan berubah nama menjadi bantuan sosial, tetapi jadikan CSR sebagai alat penompang keberhasilan kawasan untuk menunjang peningkatan pendapatan daerah agar maish-masing pihak dapat saling menguntungkan dan mengetahui keberadaan masing-masing sehingga tidak ada kaum yang termarginalkan di kawasannya sendiri.

\section{DAFTAR PUSTAKA}

Bernstein H. 2008. Class Dynamic of Agrarian Change. Halifax, Hobsbwam : Fernwood Publishing.
Bintarto. 1986. Urbanisasi dan Permasalahannya. Jakarta (ID) : Ghalia Indonesia.

[BPS] Badan Pusat Statistik. 2010. Jumlah Penduduk di Indonesia [Internet]. (2010, [2014 September 16]): Indonesia (ID). Tersedia pada http://www.bps.go.id/tab sub/view.php?t abel=1\&id subyek=12

[BPS] Badan Pusat Statistik. 2014. Kecamatan Bungoro dalam Angka. Indonesia (ID).

Djajadiningrat ST. 2001. Pemikiran Tantangan dan Permasalahan Lingkungan. Bandung (ID) : Studio Tekno Ekonomi ITB Bandung.

Dinas Pertambangan dan Energi. 2014. Laporan Triwulan Pelaksanaan IUP PT Semen Tonasa. Indonesia (ID)

[ESDM] Energi dan Sumber Daya Mineral. 2014. Data Eksplorasi dan Eksploitasi Sumberdaya pertambangan [Internet]. [2014 September 2014]. Indonesia (ID). Tersedia pada www.esdm.go.id

Harsono B. Djambatan. 1994. Hukum Agraria Indonesia. Jakarta (ID) : Raja Grafindo Persada.

[IPB] Institut Pertanian Bogor. 2012. Pedoman Penulisan Karya Ilmiah. Bogor (ID) : IPB Press.

Kristanto P. 2002. Ekologi Industri. Yogyakarta (ID) : ANDI Yogyakarta dan Lembaga Penelitian dan Pengabdian kepada Masyarakat Universitas Kristen PETRA Surabaya.

Kurniawan Y. 2013. Pola Kehidupan Sosial Ekonomi dan Strategi Bertahan Masyarakat Sekitar Industri (Studi Kasus Di Kelurahan Jetis, Kecamatan Sukoharjo, Kabupaten Sukoharjo) [Internet]. [2013 September]. Surakarta (ID) : Universitas Sebelas Maret Surakarta.

Makkulau M, Farid W. 2007. Sejarah dan Kebudayaan Pangkep. Pangkep : Pemkab Pangkep.

Mashud M. 2004. Sosiologi Teks Pengantar dan Terapan. Dwi N dan Bagong S, 
editor. Jakarta : Kencana Prenada Media Group.

Mangkusubroto K. 1995. Mining Investment Policy in Indonesia. Current Issues and Future Outlook. Indonesia Mining Journal [Internet] 1 November 2014; Vol. 1(3). Hal 60. Tersedia pada : http://isjd.pdii.lipi.go.id/index.php/Search .html?act=tampil\&id=7856 .

Mutakim A. Kamil. Pasya, G. 2003. Dinamika Masyarakat Indonesia. Jakarta (ID): Departemen Pendidikan Nasional. Hal : 141-188.

Nasihih, Lutfhi Ahmad.Razif. Fauzi, M. 2010. Kronik Agraria Indonesia Memperluas Imajinasi Lintas Zaman, Sektor dan Aktor. Yogyakarta (ID) : STPN Press

Nasikun. 1996. Urbanisasi dan Kemiskinan di Dunia Ketiga. Yogyakarta (ID) : PT Tiara Wacana.

Prayitno Duwi. 2013. Analisis Korelasi, Regresi dan Multivariate dengan SPSS, Yogyakarta (ID) : Penerbit Gava Media.

Redi A. 2014. Hukum Pertambangan. Jakarta (ID) : Gramata.

Rusli Said. 1992. Penduduk dan Masalah Pangan di Indonesia. Tjondronegoro, editor. Bogor (ID)b: OPF-IPB.

Salim HS. 2005. Hukum Pertambangan di Indonesia. Jakarta (ID) : PT RajaGrafindo Persada.

Sajogyo. 1985. Penduduk dan Pola Penggunaan Tanah dalamS.M.P.Tjondronegoro, S. Rusli dan U. Tuanaya (Penyunting) Ilmu Kependudukan : Suatu Kumpulan Bacaan. Jakarta (ID) : Erlangga.

Sinaga R.S. 1978. Beberapa Bukti yang Menunjukkan Adanya Pergeseran Pola Kesempatan Kerjad i Pedesaan Jawa, Sebab-sebab Pergeseran Tersebut dan Implikasinya. Tjondronegoro, editor. Bogor (ID) : OPF-IPB.

Singarimbun M. 1989. Metode Penelitian Survei. Sofian E, editor. Jakarta (ID) : Pustaka LP3ES.

Sitorus, MT Felix dkk. 2008. Laporan Hasil Penelitian Perubahan Struktur Agraria dan Digferensiasi Kesejahteraan Petani. Bogor (ID) : IPB bekerjasama dengan Sekretariat Badan Penelitian dan Pengembangan Pertanian.

Soekanto S. Sosiologi Kontemporer. Jakarta (ID) : CV Rajawali.

Soetarto E. 2010. Kronik Agraria Indonesia Memperluas Imajinasi Lintas Zaman, Sektor dan Aktor. Yogyakarta (ID) : STPN Press

Sufren. Natanael, Yonathan. 2014. Belajar Otodidak SPSS Pasti Bisa. Jakarta (ID) : PT. Gramedia

Suharto E. 2005. Membangun Masyarakat Memberdayakan Rakyat "Kajian Strategi Pembangunan Kesejahteraan Sosial dan Pekerjaan Sosial”. Bandung (ID) : Refika Aditama.

Supriadi. 2006. Hukum Agraria. Jakarta (ID) : Sinar Grafika.

Tauchid M. 2009. Masalah Agraria Sebagai Masalah Penghidupan dan Kemakmuran Rakyat Indonesia. Yogyakarta: STPN Press. 691 hal.

Wiradi G 2009. Seluk Beluk Masalah Agraria, Reforma Agraria dan Penelitian Agraria. Bogor (ID) : SAINS Press

Zulkifli A. 2014. Pengelolaan Tambang Berkelanjutan. Yogyakarta (ID) : Graha Ilmu. 
Nurlaila \& Soetarto /JSKPM 1(1): 81-96 